\title{
MENINGKATKAN MOTIVASI BELAJAR SISWA MELALUI PENGEMBANGAN TES BAKAT SKOLASTIK DALAM MENGHADAPI UJIAN UTBK DAN SBMPTN DIERA NEW NORMAL COVID-19
}

\author{
SUTARJO \\ MAN Insan Cendekia Sorong \\ Email : sutarjosorong2@gmail.com
}

\begin{abstract}
ABSTRAK
Tujuan dari penelitian ini adalah untuk mengetahui tingkat kesulitan butir soal dari masingmasing bentuk soal tes baik UTBK, SBMPTN maupun TBS bagi siswa MAN IC Sorong, selanjutnya akan di kelompokan dan dilakukan analisis parameter butir soal dengan aplikasi BILOG-MG for windows dari analisis didapatkan kecocokan model PL 2 dan PL 3 memiliki kesuaian bahwa 100\% termuat instrument dapat menentukan siswa mempunyai kemampuan berpikir dapat dikatagorikan tinggi, sedang, dan rendah. Tingkat kesulitan butrir soal UTBK menunjukkan sebagian ada yang memeiliki tingkat kesulitan yang sama yaitu pada 1-PL sebesar $25 \%$ dan 2-PL sebesar $25 \%$. Tingkat kesulitan butrir soal SBMPTN menunjukkan sebagain memeiliki tingkat kesulitan yang sama yaitu pada 1-PL sebesar $20 \%$ dan 3-PL sebesar $20 \%$. Pada tipe soal juga ditemukan butir soal mudah yang sma anata 2-PL (25\%)dan 3-PL (25\%). Tingkat kesulitan butir soal TBS yang meliputi tipe soal verbal, numerik, logika dan spasial memiliki tingkat kesulitan yang sama anatara tipe soal logika dan spasial. Pada logika yaitu pada model 1-PL dan 2-PL (16\%) sedangkan spasial pada model 1-PL dan 2-PL (12\%). Berdasarkan hasil analisis indeks daya beda buitr soal pada soal UBK, SBMPTN, dan TBS diteliti pada model IRT yaitu 2-PL dan 3-PL dapat disimpulkan bahwa 100\% termuat instrument. Sedangkan analisis indeks tebakan semu baik 97,50\% dan tidak baik sebesar 2,50\% pada soal UTBK. SBMPTN tebakan semu baik 95,00\% dan tidak baik sebesar 5,00\% .Untuk tebakan semu TBS didapat bahwa tipe soal verbal, numerik, logika dan spasial mempunyai tebakan semu yang baik paling banyak adalah tipe soal verbal $84,00 \%$, spasial $76 \%$, logika 72 $\%$ dan $68 \%$ numerik. Dengan adanya indeks tebakan semu pada model logistik tiga parameter, memungkinkan bagi peneliti untuk mendeteksi subjek yang menjawab dengan acak atau subjek yang memiliki kemampuan rendah yang menjawab butir soal dengan benar. Dari hasil analisa ini menjadi patokan atau acuan untuk perbaikan dengan memberikan bimbingan yang intensif agar nilai UTBK dan SBMPTN di tahun 2022 di MAN IC Sorong akan lebih baik.
\end{abstract}

Kata kunci : Motivasi Belajar, tes bakat skolatik ijian UTBK dan SBMPTN diera new normal

\section{ABSTRACT}

The purpose of this study was to determine the level of difficulty of the items from each form of test questions, both UTBK, SBMPTN and TBS for MAN IC Sorong students, then grouped and analyzed the parameters of the items using the BILOG-MG application for windows. The suitability of the PL 2 and PL 3 models has an agreement that 100\% of the instruments contained can determine students' thinking abilities which can be categorized as high, medium, and low. The difficulty level of the UTBK items shows that some have the same difficulty level, namely in 1 -PL by $25 \%$ and 2-PL by $25 \%$. The difficulty level of the SBMPTN items shows that most of them have the same level of difficulty, namely at 1-PL by $20 \%$ and 3-PL by $20 \%$. The type of questions also found easy items which were the same as 2-PL (25\%) and 3-PL (25\%). The difficulty level of TBS items which include verbal, numerical, logical and spatial types has the same level of difficulty between logical and spatial types of questions. The logic is in the 1-PL and 2-PL models (16\%) while the spatial is in the 1-PL and 2-PL models (12\%). Based on the results of the analysis of the discriminatory power index of the questions on the UBK, SBMPTN, and TBS questions examined on the IRT model, namely 2-PL and 3-PL, it can be concluded that $100 \%$ of the instruments contained. While the quasi-guess index analysis is good at $97.50 \%$ and not good at $2.50 \%$ on the UTBK questions. SBMPTN pseudo-guesses are good 
at $95.00 \%$ and not good at $5.00 \%$. For TBS pseudo-guesses, it is found that the types of verbal, numerical, logical and spatial questions have good quasi-guesses, mostly verbal type questions $84.00 \%$, spatial $76 \%$, logical $72 \%$ and $68 \%$ numeric. With the quasi-guess index in the threeparameter logistic model, it is possible for researchers to detect subjects who answered randomly or subjects with low ability who answered the items correctly. From the results of this analysis, it becomes a benchmark or reference for improvement by providing intensive guidance so that the UTBK and SBMPTN scores in 2022 at MAN IC Sorong will be better.

Key words : Learning motivation, scholastic aptitude test UTBK and SBMPTN exams in the new normal era

\section{PENDAHULUAN}

Pada masa Pandemi COVID-19 telah merubah cara pandang pembelajaran yang harus dilakukan secara tatap muka menuju kepada pembelajaran secara online Guru harus mampu merancang strategi pemebelajaran yang lebih efektif sehingga siswa mampu memahami secara kognitif materi yang diajarkan berbeda dengan belajar tatap muka di era normal (Sintema,E,J.2020). Diera new normal atau era normal baru ini akan dilkasanakan Pembelajaran Tatap Muka (PTM) sebagaimana tertuang dalam surat keputusan bersama menteri Pendidikan dan Kebudayaan, Menteri Agama, Menteri Kesehatan dan Menteri Dalam Negeri Republik Indonesia, Nomor 03/KB/2021, Nomor 384 tahun 2021, Nomor 384 Tahun 2021, Nomor HK.01.08/Menkes/4242/2021, Nomor 440-717 tahun 2021 tentang panduan penyelenggaraan pembelajaran di masa pandemi Coronavirus Disease (COVID-19). Pelaksanaan Tahun pelajaran 2021 -2022 PTM terbatas dan tidak diwajibkan dan harus memperhatikan kebijakan pemerintah tentang PPKM dan mengacu pada ketentuan SKB empat menteri. Kegiatan pembelajaran di MAN Insan Cendekia Sorong termasuk zona hijau telah dibuka kembali guru dan siswa tetap wajib mentaati protokol kesehatan sejak berangkat dari rumah/asrama wajib memakai masker, menjaga jarak, cuci tangan dengan sabun, dan sebelum masuk kelas diperhatikan kesehatannya untuk mencegah penularan virus COVID-19.

Pada masa pandemi COVID-19 ternyata membawa dampak yang kurang baik bagi siswa MAN IC Sorong mengalami kebingungan dan merasa jenuh terhadap materi pembelajaran di kelas dan dirasakan kurang menerima materi dengan baik padahal guru sudah berusaha menggunakan berbagai strategi dan model pembelajaran yang sesuai. Berdasarkan observasi di kelas XII jurusan IPA dan IPS terkesan belajarnya kurang termotivasi, membosankan, kurang memeperhatikan gurunya di kelas dan terkesan banyak siswa yang mengantuk. Sebagai mana pendapat (Amalia,N.2020) dampak dari kondisi dimasa pandemi COVID-19 ternyata pembelajaran secara daring berdampak pada psikologis seperti lelah dalam mengikuti pelajaran, bosan dan tidak mampu memahami pelajaran. Kurangnya motivasi dikarenakan akibat pembelajaran daring hampir 2 tahun selama pandemi COVID-19. Potensi siswa di kelas kurang tergugah semangatnya padahal setiap siswa memiliki bakat dan minat yang ada dalam dirinya, potensi ini terkadang tidak tergali secara maksimal oleh guru maupun orangtuanya dan tidak mengukur potensi bakat siswa tersebut. Untuk mengatasi masalah/solusi tersebut diatas peneliti ingin melakukan TBS (Tes Bakat Skolastik/Scholastic Atitude Test) untuk mengetahui potensi bakat ini sangat penting sekali sesuai prosedur dapat meningkatkan motivasi belajar dan kepercayaan kepada diri siswa semua itu muaranya adalah untuk mencapai suatu kesuksesan dalam belajar dalam meraih prestasi yang lebih baik. Kurangnya motivasi belajar siswa akan dikawatirkan hasil ujian UTBK dan SBMPTN tahun 2022 akan mengalami kemrosotan. Tes TBS paling banyak diaplikasikan dalam dunia pendidikan (Asrijanty,2014). Sedangkan menurut (Sunartoyo, 2015) Tes ini sangat baik dilakukan untuk kepentingan akademik siswa, karena akan menentukan kesuksesan belajar. TBS ini biasanya dilakukan kepada siswa yang duduk ditingkat menengah SMA/MA atau SMK yang akan melanjutkan studi ke jenjang yang lebih tinggi sehingga ketika memilih jurusan di perguruan tinggi tidak salah pilih. Soal TBS ini sudah melalui tahap uji ilmiah dalam dunia pendidikan dimana tes tersebut didasarkan pada teori-teori terkait dalam pengembangan kebakatan siswa. Yang 
menjadi permasalahan siswa di MAN IC Sorong adalah rendahnya motivasi belajar siswa sehingga mempengaruhi hari hasil prestasi belajar yanag akan dikwatirkan nilai UTBK dan SBMPTN akan rendah solusinya adalah peneliti melakukan Tes Bakat Skoltasik (TBS).

\section{METODE PENELITIAN}

Penelitian ini menggunakan pendekatan kuantitatif deskriptif yaitu dengan cara mendeskripsikan karakteristik instrumen TBS (Scholastic Aptitude Test), instrumen UTBK, dan instrument SBMPTN ditinjau dari tingkat kesulitan butir soal, indeks daya beda butir, indeks tebakan semu butir, soal fungsi informasi tes, dan kesalahan pengukuran tes. Rancangan penelitian ini sebelum dan sudah melakukan tes TBS siswa diberikan soal preetes - postes UTBK dan SBMPTN. Populasi dalam penelitian ini adalah seluruh siswa MAN Insan Cendekia Sorong pada Tahun Pelajaran 2021-2022 dan yang menjadi sampel penelitian ini adalah siswa kelas XII sebanyak 88 siswa jurusan IPA sebanyak 68 siswa dan jurusan IPS sebanyak 20 siswa. Alasan peneliti mengambil sampel ini bertujuan untuk mempersiapkan siswa dalam mengahadapi ujian UTBK dan SBMPTN pada tahun 2022. Data Penelitian ini berasal dari nilai TBS, nilai preetes-postes UTBK, dan nilai preetes-postes SBMPTN yang sudah terkumpul dari jawaban siswa. Semua data yang terkumpul selanjutnya akan di kelompokan dan dilakukan analisis parameter butir soal dengan aplikasi BILOG-MG For Windows (Toit, M. D. (2013).

Dalam pengukuran ketiga jenis instrument yang diperoleh berasal dari jawaban siswa; a) instrumen TBS terdiri dari 1) tes verbal atau bahasa, 2) tes numerik atau angka, 3) tes logika, dan 4) tes spasial atau gambar. b) instrument pree test-post test soal UTBK c. instrument pree test-post test soal SBMPTN. Ketiga bentuk instrumen ini adalah soal pilihan ganda (multiple choice) dengan lima item jawaban. Siswa diminta untuk menjawab pertanyaan dengan satu jawaban yang dianggap paling benar. Berikut ini adalah tabel instrument soal tes TBS dan instrument soal UTBK-SBMPTN.

Tabel 1. Instrument soal tes skolastik

\begin{tabular}{|l|l|c|l|}
\hline No. & $\begin{array}{l}\text { Tipe bentuk Soal } \\
\text { Tes }\end{array}$ & Jumlah soal & Waktu \\
\hline 1. & Tes Verbal (bahasa) & 25 & 30 menit \\
\hline 2. & Tes Numerik (angka) & 25 & 30 menit \\
\hline 3. & $\begin{array}{l}\text { Tes Logika } \\
\text { (penalaran) }\end{array}$ & 25 & 30 menit \\
\hline 4. & Tes Spasial (gambar) & 25 & 30 menit \\
\hline
\end{tabular}

Tabel 2. Instrument soal tes UTBK dan SBMPTN

\begin{tabular}{|l|l|c|l|}
\hline No. & $\begin{array}{l}\text { Tipe bentuk Soal } \\
\text { Tes }\end{array}$ & $\begin{array}{l}\text { Jumlah } \\
\text { soal }\end{array}$ & Waktu \\
\hline 1. & Tes UTBK & 40 & 120 menit \\
\hline 2. & Tes SBMPTN & 40 & 120 menit \\
\hline
\end{tabular}

Data yang diperoleh dari TBS, UTBK dan SBMPTN jawaban siswa akan dianalisis dari ketiga bentuk soal tersbut secara tersendiri dan terpisah. Dari data yang terkumpul akan digunakan untuk memenuhi standar IRT yang berkaiatan dengan unidimensionalitas dan independen yang ada (Retnawati, 2014). Data yang didapatkan akan dianalisa dengan IRT guna untuk mengetahui parameter butir soal dari TBS, UTBK, dan SBMPTN Yang menjadi parameter butir soal ini terdiri dari; (a).indeks daya beda (discrimininatory index), (b).tingkat sulit (difficulty level) dan (c).indeks tebakan semu (pseudo guess index). Sebelum di analisis karakter butir soal tadi harus diuji dengan menggunakan chi-squar (chi-kuadrat) pada signifikan $(\alpha)=0,01$ dari program BILOG-MG for windows mempunyai nilai yang sudah dibakukan (default) (Mislevy \& Bock, 2010). Menurut Van der Linden, Wim J.; Barrett, Michelle D. (2016) Ada 3 Analisis model PL (Parameter Logistic) (1-PL, 2-PL, dan 3-PL) juga dilakukan dengan bantuan program BILOG. Estimasi parameter kemampuan dilakukan 
menggunakan formula yang disajikan oleh Hambleton \& Swaminathan (2015) adalah sebagai berikut:

$$
\begin{aligned}
& \text { Model 1-PL } \quad P_{i}(\theta)=\frac{\theta^{D\left(\theta-b_{i}\right)}}{1+B_{\left(\theta-\theta-b_{i}\right)}} \\
& \text { Model 2-PL } \quad P_{i}(\theta)=\frac{e^{\operatorname{ait}\left(\theta-b_{i}\right)}}{1+e^{\operatorname{Dai}\left(\theta-b_{i}\right)}} \\
& \text { Model 3-PL } P_{i}(\theta)=c_{i}+\left(1-c_{i}\right) \frac{\theta^{\operatorname{Dai}\left(\theta-b_{i}\right)}}{1+\theta^{\operatorname{Dai}\left(\theta-b_{i}\right)}}
\end{aligned}
$$

\section{HASIL DAN PEMBAHASAN}

Pelaksanaan penelitian ini untuk meningkatkan motivasi belajar melalui pengembangan Tes Bakat Skolastik (TBS) bagi siswa kelas XII jurusan IPA dan IPS pada bulan September sampai dengan Oktober 2021. Peneliti ingin mengetahui penerapan tes TBS siswa dampak peningkatan soal preetes dan postes pada soal-soal UTBK maupun SBMPTN tahun 2020 hal ini untuk mengistimasi ujian UTBK dan SBMPTN di tahun 2022. Berikut ini adalah data hasil repakapan

\begin{tabular}{|c|c|c|c|}
\hline \multicolumn{4}{|c|}{ PEROLEHAN NILAI PREETES UTBK } \\
\hline No. & $\begin{array}{l}\text { Interval } \\
\text { Nilai }\end{array}$ & Frekuensi & Persentase \\
\hline 1. & $0-10$ & 0 & 0 \\
\hline 2. & $11-20$ & 1 & $1,14 \%$ \\
\hline 3. & $21-30$ & 3 & $3,41 \%$ \\
\hline 4. & $31-40$ & 12 & $13,63 \%$ \\
\hline 5. & $41-50$ & 29 & $32,95 \%$ \\
\hline 6. & $51-60$ & 36 & $40.92 \%$ \\
\hline 7. & $61-70$ & 5 & $5,68 \%$ \\
\hline 8. & $71-80$ & 2 & $2,27 \%$ \\
\hline 9. & $81-90$ & 0 & 0 \\
\hline 10. & $91-100$ & 0 & 0 \\
\hline \multicolumn{2}{|c|}{ Jumlah } & 88 & \\
\hline
\end{tabular}
nilai yang diperoleh sebagai berikut;

\begin{tabular}{|c|c|c|c|}
\hline \multicolumn{4}{|c|}{$\begin{array}{l}\text { PEROLEHAN NILAI PREETES } \\
\text { SBMPTN }\end{array}$} \\
\hline No. & $\begin{array}{c}\text { Interval } \\
\text { Nilai }\end{array}$ & Frekuensi & Persentase \\
\hline 1. & $0-10$ & 0 & 0 \\
\hline 2. & $11-20$ & 2 & $2.27 \%$ \\
\hline 3. & $21-30$ & 6 & $6,82 \%$ \\
\hline 4. & $31-40$ & 15 & $17,05 \%$ \\
\hline 5. & $41-50$ & 26 & $29,55 \%$ \\
\hline 6. & $51-60$ & 32 & $36,35 \%$ \\
\hline 7. & $61-70$ & 6 & $6,82 \%$ \\
\hline 8. & $71-80$ & 1 & $1,14 \%$ \\
\hline 9. & $81-90$ & 0 & 0 \\
\hline 10. & $91-100$ & 0 & 0 \\
\hline & lah & 88 & \\
\hline
\end{tabular}

Tabel 1. Daftar nilai prestes UTBK dan SBMPTN

\begin{tabular}{|c|c|c|c|}
\hline \multicolumn{4}{|c|}{ PEROLEHAN NILAI PREETES TBS } \\
\hline No & $\begin{array}{l}\text { Interval } \\
\text { Nilai }\end{array}$ & Frekuensi & $\begin{array}{l}\text { Persentas } \\
\mathrm{e}\end{array}$ \\
\hline 1. & $0-10$ & 0 & 0 \\
\hline 2. & $11-20$ & 0 & 0 \\
\hline 3. & $21-30$ & 0 & 0 \\
\hline 4. & $31-40$ & 2 & $2,27 \%$ \\
\hline 5. & $41-50$ & 1 & $1,14 \%$ \\
\hline 6. & $51-60$ & 12 & $13,64 \%$ \\
\hline 7. & $61-70$ & 24 & $27,28 \%$ \\
\hline 8. & $71-80$ & 19 & $21,60 \%$ \\
\hline 9. & $81-90$ & 9 & $10,23 \%$ \\
\hline 10. & $91-100$ & 1 & $1,14 \%$ \\
\hline & Jumlah & 88 & \\
\hline
\end{tabular}

Tabel 2. Nilai Tes TBS

Tabel 3. Nilai Postes UTBK dan SBMPTN 
Vol 2. No 1. Januari 2022 P-ISSN : 2774-8022, e-ISSN : 2774-5791

\begin{tabular}{|c|c|c|c|}
\hline \multicolumn{4}{|c|}{ PEROLEHAN NILAI POSTES UTBK } \\
\hline No. & $\begin{array}{c}\text { Interval } \\
\text { Nilai }\end{array}$ & Frekuensi & Persentase \\
\hline 1. & $0-10$ & 0 & 0 \\
\hline 2. & $11-20$ & 0 & 0 \\
\hline 3. & $21-30$ & 0 & 0 \\
\hline 4. & $31-40$ & 2 & $2,27 \%$ \\
\hline 5. & $41-50$ & 7 & $7,95 \%$ \\
\hline 6. & $51-60$ & 27 & $30,67 \%$ \\
\hline 7. & $61-70$ & 31 & $35,24 \%$ \\
\hline 8. & $71-80$ & 12 & $13,64 \%$ \\
\hline 9. & $81-90$ & 6 & $6,82 \%$ \\
\hline 10. & $91-100$ & 3 & $3,41 \%$ \\
\hline \multicolumn{2}{|c|}{ Jumlah } & 88 & \\
\hline
\end{tabular}

\begin{tabular}{|c|c|c|c|}
\hline \multicolumn{4}{|c|}{$\begin{array}{l}\text { PEROLEHAN NILAI POSTES } \\
\text { SBMPTN }\end{array}$} \\
\hline No. & $\begin{array}{c}\text { Interval } \\
\text { Nilai }\end{array}$ & Frekuensi & Persentase \\
\hline 1. & $0-10$ & 0 & 0 \\
\hline 2. & $11-20$ & 0 & 0 \\
\hline 3. & $21-30$ & 1 & $1,17 \%$ \\
\hline 4. & $31-40$ & 4 & $4,55 \%$ \\
\hline 5. & $41-50$ & 2 & $2,27 \%$ \\
\hline 6. & $51-60$ & 13 & $14,76 \%$ \\
\hline 7. & $61-70$ & 38 & $43,18 \%$ \\
\hline 8. & $71-80$ & 19 & $21,57 \%$ \\
\hline 9. & $81-90$ & 6 & $6,82 \%$ \\
\hline 10. & 91-100 & 5 & $5,68 \%$ \\
\hline & nlah & 88 & \\
\hline
\end{tabular}

Berdasarkan hasil rekapan interval nilai ternyata TBS membawa dampak pengaruh yang signifikan namun nilai belum sangat memuaskan. Data yang diperoleh mengalami peningkatan setelah dilakukan penerapan tes TBS mengangapa siswa tidak bisa menjawab semua benar masih banyak yang salah. Peneliti juga ingin mengetahui tingkat kesulitan butir soal dari masing masing bentuk soal tes baik UTBK, SBMPTN maupun TBS, selanjutnya akan di kelompokan dan dilakukan analisis parameter butir soal dengan aplikasi BILOG-MG for windows. Dalam pengukuran ketiga jenis instrument yang diperoleh berasal dari jawaban siswa; a) instrumen TBS terdiri dari 1) tes verbal atau bahasa, 2) tes numerik atau angka, 3) tes logika, dan 4) tes spasial atau gambar. b) instrument preetes-postes soal UTBK c). instrument preetest-postest soal SBMPTN.

Instrumen UTBK, SBMPTN dan TBS akan dianalisis secara tersendiri masing - masing tiap bentuk soal tes. Instrumen yang dimaksud ketepatan dalam menjawab masing masing butir soal ini adalah (a). indeks daya beda (discrimininatory index), (b).tingkat sulit (difficulty level) dan (c). indeks tebakan semu (pseudo guess index), fungsi uji inforamsi TIF (Test Information Function) dan standard kesalahan SE (Standard Error) yang merupakan representasi koefisien reliabilitas dan kesalahan pengukuran dalam teori tes. Kesesuain jawaban dan ketepatan butir soal pada instrumen TBS akan di analisis dengan menggunakan uji statistik chi-squar menyajikan butir-butir TBS yang teridentifikasi sesuai dengan model ( $f i t)$ maupun butir soal teridentifikasi tidak sesuai dengan model (misfit). Butir soal yang sesuai dengan modelnya menunjukkan model IRT menunjukkan respon yang paling baik terhadap butir soal yang diuji (Embretson $\&$ Reise, 2000). Butir soal dikatakan memiliki fit model jika probabilitas $\chi^{2} \geq 0,01$ atau taraf signifikansi $(\alpha) \geq 0,01$.

Tabel 4: Kesusain butir soal UTBK sebagai berikut;

\begin{tabular}{|l|c|c|c|c|c|c|}
\hline \multirow{3}{*}{ Tipe soal } & \multicolumn{6}{|c|}{ Model Parameter Logistic (PL) } \\
\cline { 2 - 7 } & \multicolumn{2}{|c|}{ 1-PL } & \multicolumn{2}{c|}{ 2-PL } & \multicolumn{2}{c|}{ 3-PL } \\
\cline { 2 - 7 } & $\begin{array}{c}\text { Fit } \\
(\mathrm{jml} / \%)\end{array}$ & $\begin{array}{c}\text { Misfit } \\
(\mathrm{jml} / \%)\end{array}$ & $\begin{array}{c}\text { Fit } \\
(\mathrm{jml} / \%)\end{array}$ & $\begin{array}{c}\text { Misfit } \\
(\mathrm{jml} / \%)\end{array}$ & $\begin{array}{c}\text { Fit } \\
(\mathrm{jml} / \%)\end{array}$ & $\begin{array}{c}\text { Misfit } \\
(\mathrm{jml} / \%)\end{array}$ \\
\hline \multirow{2}{*}{ UTBK } & 6 & 34 & 4 & 37 & 6 & 34 \\
\cline { 2 - 7 } & $15,00 \%$ & $85,00 \%$ & $10,00 \%$ & $92,00 \%$ & $15,00 \%$ & $85,00 \%$ \\
\hline
\end{tabular}

Hasil analisis kesuain butir soal UTBK terdapat pada lampiran 1 dapat diklasifikasikan bahwa pada model 2-PL fit memilki jumlah butir soal lebih sedikit dibandingkan pada fit 1-PL dan 3-PL. Pada soal UTBK pada model 1-PL dan 3-PL fit memberikan jumlah yang sama. Dari data tersebut dapat disimpulkan bahwa butir soal tes sesaui dengan model 1-PL dan 3-PL. Pada butir soal 3-PL lebih banyak 2-PL hal ini akan mempengaruhi fit butir soal tersebut . Pada model 
2-PL terdapat fit yang sedikit dari 1-PL dan 3-PL, disebabkan indek daya beda butir soal dibatasi (akomodasi) sehingga variasinya tidak dijadikan sebagai para meter seperti pada 1-Pl dan 3-PL dengan keterbatasan akan menjadi tidak cukup kuat.

Tabel 5 : Kesusain butir soal SBMPTN sebagai berikut;

\begin{tabular}{|c|c|c|c|c|c|c|}
\hline \multirow{3}{*}{ Tipe soal } & \multicolumn{6}{|c|}{ Model Parameter Logistic (PL) } \\
\cline { 2 - 7 } & \multicolumn{2}{|c|}{ 1-PL } & \multicolumn{2}{|c|}{ 2-PL } & \multicolumn{2}{c|}{ 3-PL } \\
\cline { 2 - 7 } & $\begin{array}{c}\text { Fit } \\
(\mathrm{jml} / \%)\end{array}$ & $\begin{array}{c}\text { Misfit } \\
(\mathrm{jml} / \%)\end{array}$ & $\begin{array}{c}\text { Fit } \\
(\mathrm{jml} / \%)\end{array}$ & $\begin{array}{c}\text { Misfit } \\
(\mathrm{jml} / \%)\end{array}$ & $\begin{array}{c}\text { Fit } \\
(\mathrm{jml} / \%)\end{array}$ & $\begin{array}{c}\text { Misfit } \\
(\mathrm{jml} / \%)\end{array}$ \\
\hline SBMPTN & 4 & 36 & 29 & 11 & 27 & 13 \\
\cline { 2 - 7 } & $10 \%$ & $90,00 \%$ & $72,50 \%$ & $27,50 \%$ & $67,50 \%$ & $32,50 \%$ \\
\hline
\end{tabular}

Hasil analisis kesuain butir soal SBMPTN terdapat pada lampiran 2 dapat diklasifikasikan bahwa pada model 1-PL fit memilki jumlah butir soal lebih sedikit dibandingkan pada fit 2-PL dan 3-PL. Pada soal SBMPTN pada model 2-PL dan 3-PL fit memberikan jumlah mendekati jumlah yang sama. Dari data tersebut dapat disimpulkan bahwa butir soal tes sesaui dengan model 2-PL dan 3-PL. Pada butir soal 3-PL lebih banyak 2-PL hal ini akan mempengaruhi fit butir soal tersebut . Pada model 1-PL terdapat fit yang sedikit dari 2-PL dan 3-PL, disebabkan indek daya beda butir soal dibatasi (akomodasi) sehingga variasinya tidak dijadikan sebagai para meter seperti pada 2-Pl dan 3-PL dengan keterbatasan akan menjadi tidak cukup kuat.

Tabel 6. Kesusain butir soal TBS sebagai berikut;

\begin{tabular}{|c|c|c|c|c|c|c|}
\hline \multirow{3}{*}{ Tipe soal } & \multicolumn{6}{|c|}{ Model Parameter Logistic (PL) } \\
\hline & \multicolumn{2}{|c|}{ 1-PL } & \multicolumn{2}{|c|}{ 2-PL } & \multicolumn{2}{|c|}{ 3-PL } \\
\hline & $\begin{array}{c}\text { Fit } \\
(\mathrm{jml} / \%)\end{array}$ & $\begin{array}{c}\text { Misfit } \\
(\mathrm{jml} / \%)\end{array}$ & $\begin{array}{c}\text { Fit } \\
(\mathrm{jml} / \%)\end{array}$ & $\begin{array}{c}\text { Misfit } \\
\text { (jml/\%) }\end{array}$ & $\begin{array}{c}\text { Fit } \\
(\mathrm{jml} / \%)\end{array}$ & $\begin{array}{c}\text { Misfit } \\
\text { (jml/\%) }\end{array}$ \\
\hline \multirow[t]{2}{*}{ Verbal } & 10 & 15 & 22 & 3 & 23 & 2 \\
\hline & $40,00 \%$ & $60,00 \%$ & $88,00 \%$ & $12,00 \%$ & $92,00 \%$ & $8,00 \%$ \\
\hline \multirow[t]{2}{*}{ Numeric } & 12 & 13 & 22 & 3 & 21 & 4 \\
\hline & $48,00 \%$ & $52,00 \%$ & $88,00 \%$ & $12,00 \%$ & $84,00 \%$ & $16,00 \%$ \\
\hline \multirow[t]{2}{*}{ Logika } & 1 & 18 & 22 & 3 & 23 & 2 \\
\hline & $28,00 \%$ & $72,88 \%$ & $88,00 \%$ & $12,00 \%$ & $92,00 \%$ & $8,00 \%$ \\
\hline \multirow[t]{2}{*}{ Spasial } & 9 & 16 & 22 & 3 & 24 & 1 \\
\hline & $36,00 \%$ & $64,00 \%$ & $88,00 \%$ & $12,00 \%$ & $96,00 \%$ & $4,00 \%$ \\
\hline
\end{tabular}

Hasil dari analisis data kesuain butir soal TBS pada lampiran 3 dapat diklasifikasikan bahwa pada model 1-PL fit memilki jumlah butir soal lebih sedikit dibandingkan pada fit 2-PL dan 3-PL. pada soal tes verbal, numeric, logika, dan, spasial pad tipe 2-PL fit memberikan jumlah yang sama. Dari data tersebut dapat disimpulkan bahwa butir soal tes sesaui dengan model 2-PL dan 3-PL p ada butir soal 3-PL lebih banyak 2-PL hal ini akan mempengaruhi fit butir soal tersebut . Pada model 1-PL terdapat fit yang sedikit dari 2-Pl dan 3-PL, disebabkan indek daya beda butir soal dibatasi (akomodasi) sehingga variasinya tidak dijadikan sebagai para meter seperti pada 2-Pl dan 3-PL dengan keterbatasan akan menjadi tidak cukup kuat

Berdasarkan Kriteria tingkat kesulitan butir soal UTBK yang baik berada pada posisi -2 sampai +2 . Kriteria indeks daya beda butir soal UTBK pada posisi 0 sampai +2 . Pada kriteria indeks tebakan semu pada tes multiple choice terletak di sekitar 1 berbanding dengan banyaknya pilihan. Jumlah distraktor pada tipe jenis soal UTBK adalah 5, nilai maksimal adalah $1 / 5$ atau 0.2 . Berdasarkan lampiran pada tabel 4 akan terbaca, maka didapatkan rata-rata tingkat kesulitan butir soal, indeks daya beda, dan indeks tebakan semu dalam kelompok baik, jika nilai maksimal dan minimal mempuyai parameter butir soal melebihi kriteria. Apabila dibandingkan dari ketiga Parameter Logistic (PL) parameter yang bagus akan didapatkan analisis IRT 3-PL.

Berdasarkan Kriteria tingkat kesulitan butir soal SBMPTN yang baik berada pada posisi -2 sampai +2. Kriteria indeks daya beda butir soal SBMPTN pada posisi 0 sampai +2 . Pada kriteria 
indeks tebakan semu pada tes multiple choice terletak di sekitar 1 berbanding dengan banyaknya pilihan. Jumlah distraktor pada tipe jenis soal SBMPTN adalah 5, nilai maksimal adalah $1 / 5$ atau 0.2 . Berdasarkan lampiran pada tabel 4 akan terbaca, maka didapatkan rata-rata tingkat kesulitan butir soal, indeks daya beda, dan indeks tebakan semu dalam kelompok baik, jika nilai maksimal dan minimal mempuyai parameter butir soal melebihi kriteria.

Indikator tingkat kesulitan butir soal TBS yang baik berada pada posisi -2 sampai +2 . Kriteria indeks daya beda butir soal TBS pada posisi 0 sampai +2 . Pada kriteria indeks tebakan semu pada tes multiple choice terletak di sekitar 1 berbanding dengan banyaknya pilihan. Jumlah distraktor pada tipe jenis soal TBS adalah 5, nilai maksimal adalah 1/5 atau 0.2. Berdasarkan lampiran pada tabel 4 akan terbaca dari ke empat jenis soal, maka didapatkan ratarata tingkat kesulitan butir soal, indeks daya beda, dan indeks tebakan semu dalam kelompok baik, jika nilai maksimal dan minimal mempuyai parameter butir soal melebihi kriteria. Apabila dibandingkan dari ketiga Parameter Logistic (PL) parameter yang bagus akan didapatkan analisis IRT 3-PL. Sementara itu, apabila ditinjau dari parameter indeks tebakan semu, item tipe jenis soal numeric dan spasial memiliki indeks tebakan semu yang lebih tinggi dibandingkan dengan tipe soal verbal dan logika. Berikut ini adalah tabel Stastik deskriptif parameter butir soal. Tingkat kesulitan butrir soal UTBK menunjukkan sebagain ada yang memeiliki tingkat kesulitan yang sama yaitu pada 1-PL sebesar $25 \%$ dan 2-PL sebesar $25 \%$. Pada analisis model Parameter Logistic (PL) didapatkan PL yang sama dari ketiga model PL. Berikut ini tabel Tingkat kesulitan Butir soal UTBK.

Tabel 7. Tabel tingkat kesulitan butir soal UTBK

\begin{tabular}{|l|l|l|l|}
\hline \multirow{3}{*}{ Model } & \multicolumn{3}{|c|}{ Tipe Soal UTBK } \\
\cline { 2 - 4 } & \multicolumn{1}{|c|}{ Buitir Soal dalam Jmlh (\%) } \\
\cline { 2 - 4 } & Mudah & \multicolumn{1}{|c|}{ Sedang } & Sulit \\
\hline 1-PL & $10(25 \%)$ & $20(20 \%)$ & $10(25 \%)$ \\
\hline 2-PL & $7(17,5 \%)$ & $23(57,5 \%)$ & $10(25 \%)$ \\
\hline 3-PL & $10(25 \%)$ & $22(55 \%)$ & $8(20 \%)$ \\
\hline
\end{tabular}

Hasil analisis tabel tersebut diatas merupakan tingkatan kesulitan siswa dalam menjawab soal pada model 1-PL dan 2-PL mempunyai tingkat keulitan yang sama yang dipaparkan tingkat kesulitan butir soal mudah, sedang dan sulit dan 3-PL yang berbeda.

Tabel 8. Tabel tingkat kesulitan butir soal SBMPTN

\begin{tabular}{|l|l|l|l|}
\hline \multirow{3}{*}{ Model } & \multicolumn{3}{|c|}{ Tipe Soal SBMPTN } \\
\cline { 2 - 4 } & Buitir Soal dalam Jmlh (\%) \\
\cline { 2 - 4 } & Mudah & Sedang & Sulit \\
\hline 1-PL & $12(30 \%)$ & $20(50 \%)$ & $8(20 \%)$ \\
\hline 2-PL & $10(25 \%)$ & $24(60 \%)$ & $6(15 \%)$ \\
\hline 3-PL & $10(25 \%)$ & $22(55 \%)$ & $8(20 \%)$ \\
\hline
\end{tabular}

Tingkat kesulitan butrir soal SBMPTN menunjukkan sebagain ada yang memeiliki tingkat kesulitan yang sama yaitu pada 1-PL sebesar $20 \%$ dan 3-PL sebesar $20 \%$. Pada tipe soal juga ditemukan butir soal mudah yang sma anata 2-PL (25\%)dan 3-PL (25\%). Hasil analisis model Parameter Logistic (PL) didapatkan PL yang sama dari ketiga model PL. terjadi kesimbangan yang sama tingkat butir mudah dan sulit. Sehingga tingkat kesulitaanya sedang.

Tabel 9. Tabel tingkat kesulitan butir soal TBS

\begin{tabular}{|c|c|c|c|c|c|c|}
\hline \multirow{3}{*}{ Model } & \multicolumn{2}{|c|}{ Tipe Soal Verbal } & \multicolumn{3}{|c|}{ Model } & \multicolumn{3}{|c|}{ Tipe Soal Numerik } \\
\cline { 2 - 3 } & Buitir Soal dalam Jmlh (\%) & & Buitir Soal dalam Jmlh (\%) \\
\cline { 2 - 6 } & Mudah & Sedang & Sulit \\
\cline { 5 - 6 } & & Mudah & Sedang & Sulit \\
\hline
\end{tabular}


SECONDARY : Jurnal Inovasi Pendidikan Menengah

Vol 2. No 1. Januari 2022 P-ISSN : 2774-8022, e-ISSN : 2774-5791

\begin{tabular}{|l|l|l|l|}
\hline 1-PL & $3(12 \%)$ & $5(20 \%)$ & $3(12 \%)$ \\
\hline 2-PL & $19(76 \%)$ & $16(64 \%)$ & $\begin{array}{l}17 \\
(68 \%)\end{array}$ \\
\hline $3-P L$ & $3(12 \%)$ & $4(16 \%)$ & $5(20 \%)$ \\
\hline
\end{tabular}

\begin{tabular}{|l|l|l|l|}
\hline $1-P L$ & $3(12 \%)$ & $4(16 \%)$ & $2(8 \%)$ \\
\hline $2-P L$ & $\begin{array}{l}20 \\
(80 \%)\end{array}$ & $18(72 \%)$ & $19(76 \%)$ \\
\hline $3-P L$ & $2(8 \%)$ & $3(12 \%)$ & $4(16 \%)$ \\
\hline
\end{tabular}

\begin{tabular}{|l|c|c|c|}
\hline \multirow{2}{*}{ Model } & \multicolumn{3}{|c|}{ Tipe Soal logika } \\
\cline { 2 - 4 } & Buitir Soal dalam Jmlh (\%) \\
\cline { 2 - 4 } & Mudah & Sedang & Sulit \\
\hline 1-PL & $4(30 \%)$ & $17(50 \%)$ & $4(16 \%)$ \\
\hline 2-PL & $5(20 \%)$ & $16(64 \%)$ & $4(16 \%)$ \\
\hline 3-PL & $3(12 \%)$ & $17(68 \%)$ & $5(20 \%)$ \\
\hline
\end{tabular}

\begin{tabular}{|l|c|l|c|}
\hline \multirow{2}{*}{ Model } & \multicolumn{3}{|c|}{ Tipe Soal Spasial } \\
\cline { 2 - 4 } & Buitir Soal dalam Jmlh (\%) \\
\cline { 2 - 4 } & Mudah & Sedang & Sulit \\
\hline 1-PL & $4(16 \%)$ & $\begin{array}{l}18 \\
(72 \%)\end{array}$ & $3(12 \%)$ \\
\hline 2-PL & $4(16 \%)$ & $\begin{array}{l}18 \\
(72 \%)\end{array}$ & $3(12 \%)$ \\
\hline 3-PL & $2(8 \%)$ & $\begin{array}{l}21 \\
(84 \%)\end{array}$ & $2(8 \%)$ \\
\hline
\end{tabular}

Tingkat kesulitan butir soal TBS yang meliputi tipe soal verbal, numeric, logika dan spasial memiliki tingkat kesulitan yang sama anatara tipe soal logika dan spasial. Pada logika yaitu pada model 1-PL dan 2-PL (16\%) sedangkan spasial pada model 1-PL dan 2-PL (12\%). Pada tipe soal Spasial juga memilki tingkat soal mudah yang sama pada model 1-PL dan 2-PL sehinga tingkat kesulitan pada tipe soal spasila adalah sedang. Berdasarkan hasil analisis indeks daya beda buitr soal pada soal UTBK diteliti pada model IRT yaitu 2-PL dan 3-PL dapat ditarik kesimpulan bahwa $100 \%$ termuat instrument dapat menentukan siswa mempunyai kememapuan berpikir dapat dikatagorikan tinggi, sedang ,dan rendah.

Tabel 10. Indeks Daya Beda Butir Soal SBMPTN.

\begin{tabular}{|l|c|c|}
\hline \multirow{3}{*}{ Model } & \multicolumn{2}{|c|}{ Tipe Soal UTBK } \\
\cline { 2 - 3 } & Buitir Soal dalam Jmlh (\%) \\
\cline { 2 - 3 } & Baik & Tidak Baik \\
\hline 2-PL & $40(100 \%)$ & $0(0 \%)$ \\
\hline 3-PL & $40(100 \%)$ & $0(0 \%)$ \\
\hline
\end{tabular}

Berdasarkan hasil analisis indeks daya beda buitr soal pada soal SBMPTN diteliti pada model IRT yaitu 2-PL dan 3-PL dapat ditarik kesimpulan bahwa 100\% termuat instrument dapat menentukan siswa mempunyai kememapuan berpikir dapat dikatagorikan tinggi, sedang ,dan rendah.

Tabel 11. Indeks Daya Beda Butir Soal SBMPTN
\begin{tabular}{|l|c|c|}
\hline \multirow{3}{*}{ Model } & \multicolumn{2}{|c|}{ Tipe Soal SBMPTN } \\
\cline { 2 - 3 } & Buitir Soal dalam Jmlh ( $\%)$ \\
\cline { 2 - 3 } & Baik & Tidak Baik \\
\hline 2-PL & $40(100 \%)$ & $0(0 \%)$ \\
\hline 3-PL & $40(100 \%)$ & $0(0 \%)$ \\
\hline
\end{tabular}

Berdasarkan hasil analisis indeks daya beda buitr soal pada soal TBS diteliti pada model IRT yaitu 2-PL dan 3-PL dapat ditarik kesimpulan bahwa 100\% termuat instrument dapat menentukan siswa mempunyai kememapuan berpikir dapat dikatagorikan tinggi, sedang, dan rendah.Dengan demikian siswa dapat ditentukan kemampuan bakat skolastik yang dismiliki siswa.

Tabel 12. Indeks Tabel 12. Daya beda butir soal TBS

\begin{tabular}{|c|c|c|c|}
\hline Model & Tipe Soal Verbal & Model & Tipe Soal Logika \\
\hline
\end{tabular}


Vol 2. No 1. Januari 2022 P-ISSN : 2774-8022, e-ISSN : 2774-5791

\begin{tabular}{|l|c|c|}
\hline \multirow{2}{*}{} & \multicolumn{2}{|l|}{$\begin{array}{l}\text { Buitir Soal dalam Jmlh ( } \\
\%)\end{array}$} \\
\cline { 2 - 3 } & Baik & Tidak Baik \\
\hline 2-PL & $25(100 \%)$ & $0(0 \%)$ \\
\hline 3-PL & $25(100 \%)$ & $0(0 \%)$ \\
\hline
\end{tabular}

\begin{tabular}{|l|l|c|}
\hline \multirow{2}{*}{ Model } & \multicolumn{2}{|c|}{ Tipe Soal Numerik } \\
\cline { 2 - 3 } & $\begin{array}{l}\text { Buitir Soal dalam Jmlh ( } \\
\%)\end{array}$ \\
\cline { 2 - 3 } & Baik & Tidak Baik \\
\hline 2-PL & $25(100 \%)$ & $0(0 \%)$ \\
\hline 3-PL & $25(100 \%)$ & $0(0 \%)$ \\
\hline
\end{tabular}

\begin{tabular}{|l|c|c|}
\hline \multirow{2}{*}{} & \multicolumn{2}{|l|}{$\begin{array}{l}\text { Buitir Soal dalam Jmlh ( } \\
\%)\end{array}$} \\
\cline { 2 - 3 } & Baik & Tidak Baik \\
\hline 2-PL & $25(100 \%)$ & $0(0 \%)$ \\
\hline 3-PL & $25(100 \%)$ & $0(0 \%)$ \\
\hline
\end{tabular}

\begin{tabular}{|l|l|c|}
\hline \multirow{2}{*}{ Model } & \multicolumn{2}{|c|}{ Tipe Soal Spasial } \\
\cline { 2 - 3 } & $\begin{array}{l}\text { Buitir Soal dalam Jmlh ( } \\
\%)\end{array}$ \\
\cline { 2 - 3 } & Baik & Tidak Baik \\
\hline 2-PL & $25(100 \%)$ & $0(0 \%)$ \\
\hline 3-PL & $25(100 \%)$ & $0(0 \%)$ \\
\hline
\end{tabular}

Parameter indeks daya beda tpe soal verbal, numeric, logika dan spasial, sehingga dapat disimpulkan bahwa butir soal instrumen TBS telah berfungsi dengan baik dalam membedakan bakat skolastik pada diri siswa. Pada CTT maupun IRT, indeks daya beda butir merupakan kemampuan butir untuk membedakan siswa yang memiliki kemampuan tinggi dan siswa yang memiliki kemampuan rendah. ada perbedaan mendasar dari CTT dan IRT, pada CTT tidak mempunyai satuan dan tidak menghasilkan pengukuran yang intervalnya sama. Apabila dikaitkan dengan konteks tes bakat, maka indeks daya beda butir dapat dimaknai sebagai kemampuan butir untuk membedakan subjek yang memiliki bakat tinggi dan rendah pada tes skolastik.

Indeks tebakan semu hasil prediksi tipe soal UTBK dengan kriteria nilai maksimal tebakan semu yang baik yaitu 1 banding jumlah distraktor yaitu 0.2, maka indeks tebakan semu pada semua butir dikelompokkan. Pada Parameter Logistic dihasil analisis tebakan semu $97,50 \%$ dan tebakan semu tidak baik sebesar $2,50 \%$.

Tabel 13. Indeks tebakan semu butir soal UTBK

\begin{tabular}{llllll}
\hline Tipe soal & Model & Tebakan Semu Nomor Butir & \multicolumn{2}{c}{ JumlahPersentase } \\
\hline UTBK & 3-PL & Baik & $1,2,3,4,5.6,7,8,9,10,11,12,13,14,15,1639$ & $97,50 \%$ \\
& & & $17,18,19,20,22,23,24,25,26.27,29,30$, & \\
& & $31,32,33,34,35,36,37,39,40$ & 1 & $2,50 \%$
\end{tabular}

Indeks tebakan semu hasil prediksi tipe soal SBMPTN dengan kriteria nilai maksimal tebakan semu yang baik yaitu 1 banding jumlah distraktor yaitu 0.2, maka indeks tebakan semu pada semua butir dikelompokkan. Pada Parameter Logistic dihasil analisis tebakan semu 95,00\% dan tebakan semu tidak baik sebesar 5,00\%.

\section{Tabel 14. Indeks tebakan semu butir soal SBMPTN}

\begin{tabular}{llllll}
\hline Tipe soal & Model & Tebakan Semu Nomor Butir & \multicolumn{2}{c}{ JumlahPersentase } \\
\hline SBMPTN & 3-PL & Baik & $1,2,3,4,5.6,7,8,9,10,11,12,13,14,16,1738$ & $95,00 \%$ \\
& & & $18,19,20,22,23,24,25,26.27,29,30,31$, & \\
& & $33,34,35,36,37,39,40$ & \\
& & Tidak Baik & 15,32 & 2 & $5,00 \%$
\end{tabular}

Indeks tebakan semu hasil prediksi tipe soal TBS dengan kriteria nilai maksimal tebakan semu yang baik yaitu 1 banding jumlah distraktor yaitu 0.2 , maka indeks tebakan semu pada semua butir dikelompokkan. 
Tabel 15. Indeks tebakan semu butir soal TBS

\begin{tabular}{|c|c|c|c|c|c|}
\hline \multirow{2}{*}{$\frac{\text { Tipe soal }}{\text { Verbal }}$} & \multirow{2}{*}{$\frac{\text { Model }}{3-\mathrm{PL}}$} & \multirow{2}{*}{$\begin{array}{l}\text { Tebakan Semu } \\
\text { Baik }\end{array}$} & Nomor Butir & \multicolumn{2}{|c|}{ JumlahPersentase } \\
\hline & & & $\begin{array}{l}2,3,4,5.6,7,9,10,11,12,13,14,16,17,18 \\
19,20,22,23,24,25\end{array}$ & 21 & $84,00 \%$ \\
\hline & & Tidak Baik & $1,8,15,21$ & 4 & $16,00 \%$ \\
\hline \multirow[t]{2}{*}{ Numerikal } & 3-PL & Baik & $\begin{array}{l}1,3,4,6,8,9,10,11,12,13,15,16,17 \\
18,19,24,25\end{array}$ & 17 & $68,00 \%$ \\
\hline & & Tidak Baik & $2,5,7,14,20,21,22,23$ & 8 & $32,00 \%$ \\
\hline \multirow[t]{2}{*}{ Logika } & 3-PL & Baik & $\begin{array}{l}2,3,4,6,7,9,10,12,13,14,16,17,18 \\
20,22,23,24,25\end{array}$ & 18 & $72,00 \%$ \\
\hline & & Tidak Baik & $1,5,8,11,15,19,21$ & 7 & $28,00 \%$ \\
\hline \multirow[t]{2}{*}{ Spasial } & 3-PL & Baik & $\begin{array}{l}1,3,4,6,7,8,9,10,11,12,13,15,16,17 \\
18,19,20,24,25\end{array}$ & 19 & $76,00 \%$ \\
\hline & & Tidak Baik & $2,5,14,21,22,23$ & 6 & $24,00 \%$ \\
\hline
\end{tabular}

Parameter indeks tebakan semu TBS dari analisis yang didapat bahwa tipe soal verbal, numeric, logika dan spasial mempunyai tebakan semu yang baik paling banyak adalah tipe soal verbal 84,00\%, spasial $76 \%$, logika $72 \%$ dan $68 \%$ numeric. Dengan adanya indeks tebakan semu (c) pada model logistik tiga parameter, memungkinkan bagi peneliti untuk mendeteksi subjek yang menjawab dengan acak atau subjek yang memiliki kemampuan rendah yang menjawab butir soal dengan benar dengan batasan atau lower asymptote yang wajar (Curabay, M. 2016).

\section{KESIMPULAN}

Berdasarkan Hasil penelitian membuktikan bahwa hasil tes sebelum dan sesudah preetes mengalami siswa peningkatan pada soal UTBK dan SBMPTN setelah diberikan tes TBS. Berdasarkan hasil rekapan dari perolehan nilai interval nilai ternyata belum sangat memuaskan. Peneliti ingin mengetahui tingkat kesulitan butir soal dari masing masing bentuk soal tes baik UTBK, SBMPTN maupun TBS, selanjutnya akan di kelompokan dan dilakukan analisis parameter butir soal dengan aplikasi BILOG-MG for windows dari analisis didapatkan kecocokan model PL 2 dan Pl 3 memiliki kesuaian bahwa 100\% termuat instrument dapat menentukan siswa mempunyai kememapuan berpikir dapat dikatagorikan tinggi, sedang, dan rendah. Tingkat kesulitan butrir soal UTBK menunjukkan sebagain ada yang memeiliki tingkat kesulitan yang sama yaitu pada 1-PL sebesar $25 \%$ dan 2-PL sebesar $25 \%$. Tingkat kesulitan butrir soal SBMPTN menunjukkan sebagain ada yang memeiliki tingkat kesulitan yang sama yaitu pada 1-PL sebesar $20 \%$ dan 3-PL sebesar $20 \%$. Pada tipe soal juga ditemukan butir soal mudah yang sma anata 2-PL (25 \%)dan 3-PL (25\%). Tingkat kesulitan butir soal TBS yang meliputi tipe soal verbal, numeric, logika dan spasial memiliki tingkat kesulitan yang sama anatara tipe soal logika dan spasial. Pada logika yaitu pada model 1-PL dan 2-PL (16\%) sedangkan spasial pada model 1-PL dan 2-PL (12\%). Berdasarkan hasil analisis indeks daya beda buitr soal pada soal UBK, SBMPTN, dan TBS diteliti pada model IRT yaitu 2-PL dan 3-PL dapat disimpulkan bahwa 100\% termuat instrument. Sedangkan analisis indeks tebakan semu baik $97,50 \%$ dan tidak baik sebesar 2,50\% pada soal UTBK. SBMPTN tebakan semu baik 95,00\% dan tidak baik sebesar 5,00\% .Untuk tebakan semu TBS didapat bahwa tipe soal verbal, numeric, logika dan spasial mempunyai tebakan semu yang baik paling banyak adalah tipe soal verbal 84,00\%, spasial $76 \%$, logika $72 \%$ dan $68 \%$ numeric. Dengan adanya indeks tebakan semu pada model logistik tiga parameter, memungkinkan bagi peneliti untuk mendeteksi subjek yang menjawab dengan acak atau subjek yang memiliki kemampuan rendah yang menjawab butir soal dengan benar. Dari hasil analisa ini menjadi patokan atau acuan untuk perbaikan dengan memberikan bimbingan yang intensif agar nilai UTBK dan SBMPTN di tahun 2022 di MAN IC Sorong akan lebih baik. 


\section{DAFTAR PUSTAKA}

Aeni,Nur (2012) Tes Intelegensi dan Tes Bakat . Yogyakarta: PusakaPelajar

Amalia, N. (2020) Dampak Wabah COVID-19 Terhadap Kegiatan Belajar Mengajar Di Indonesia, Jurnal Psikologi, 13 (2), pp.214-225. doi:10.35760/psi.2020.v13i2.3572.

Abedalaziz, N., \& Leng, C. H. (2013). The relationship between CTT and IRT approaches in analyzing item characteristics. The Malaysian Online Journal of Education Science, 1(1), 64-70.

Adedoyin, O. O., \& Mokobi, T. (2013). Using IRT psychometric analysis in examining the quality of junior certificate mathematics multiple choice examination test items. International Journal of Asian Social Science, 3(4), 992-1011.

Asrijanty. (2014). Validitas prediktif bakat skolastik dan prestasi belajar sebagai kriteria seleksi masuk perguruan tinggi. Jurnal Pendidikan dan Kebudayaan, 20(4), 515-534.

Curabay, M. (2016). Meta-analysis of the predictive validity of scholastic aptitude test (SAT) and American college testing (ACT) scores for college GPA (Master's Thesis). University of Denver, Denver.

Direktorat Sekolah Menengah Atas. Direktorat Jenderal Pendidikan Anak Usia Dini,Pendidikan Dasar, dan pendidikan Menengah, Kementerian Pendidikan Dan Kebudayaan. (2020). Penilaian pada Kondisi Khusus di SMA.

Fitriyani. (2020). Motivasi Belajar Mahasiswa Pada Pembelajaran Daring Selama Pandemik Covid-19. Jurnal Kependidikan: Jurnal Hasil Penelitian dan Kajian Kepustakaan di Bidang Pendidikan, Pengajaran dan Pembelajaran. 6, 166-171.

Hamdu. (2017) "Pengaruh Motivasi Belajar Siswa Terhadap Prestasi Belajar IPA di Sekolah Dasar" Vol.12No.1 ISSN 1412-565X

Hidayati,Nia. (2019) Mengembangkan Bakat dan Minat. Jakarta: PT.Raja Grafindo Persada

Huda, S (2020) "Persiapan Pendidikan di era New Normal". Availableat: https://www. maarifjatim.or.id/? mdocs-file $=503$.

Keputusan Bersama Menteri Pendidikan Dan Kebudayaan, Menteri Agama, Menteri Kesehatan, dan Menteri Dalam Negeri Republik Indonesia Nomor 03/KB/2021, Nomor 384 Tahun 2021; Nomor HK.01.08/ MENKES/4242/2021; Nomor 440-717 Tahun 2021 tentang Panduan Penyelenggaraan Pembelajaran di Masa Pandemi Coronavirus Disease 2019 (COVID-19)

Mislevy, R. J., \& Bock, R. D. (2010). BILOG-MG For Windows: Item analysis and test scoring with binary logistic models $\left(2^{\text {nd }} E d\right.$.). Mooresville: Scientific Software Inc.

Muhyiddin, M. (2020). COVID-19, New Normal, dan Perencanaan Pembangunan di Indonesia. Jurnal Perencanaan Pembangunan: The Indonesian Journal of Development Planning, 4(2),240-252. https://doi.org/10.36574/jpp.v4i2.118.

Munandar,Utami. (2017) Mengembangkan Bakat dan Kreaktivitas Anak di Sekolah. Jakarta: PT.Gramedia

Nano Sunartoyo. (2015) Buku Besar TBS (Tes Bakat Skolastik); Mudah, akurat dan dilengkapi dengan latihan soal-soal terkini, Flashbooks Yogyakarta.

Paul,Suparno.(2014) Teori Intelegensi Ganda dan Aplikasinya Di Sekolah. Yogyakarta: Kanisius

Sadirman (2016) Interaksi dan Motivasi Belajar Mengajar. Jakarta: PT. Raja Grafindo Persada

Sintema, E. J. (2020). Effect of COVID-19 on the Performance of Grade 12 Students: Implications for STEM Education. Eurasia Journal of Mathematics, Science and Technology Education, 16(7),1-6. https://doi.org/10.29333/ejmste/7893.

Toit, M. D. (2013). IRT From SSI: BILOG-for windows, Multilog, Parsclae, Testfact. United States Of America: Scientific Software International, Inc.

Uno,Hamzah B. (2018) Teori Motivasi dan Pengukuran Analisis di Bidang Pendidikan, Jakarta Bumi Aksara 
Zieba, A. (2013). The item information function in one and two-parameter logistic models-a comparison and use in the analysis of the results of school test. Didactics of Mathematics, 10(14), 87-96.http://doi.org/10.15611/dm.2013.10.08

Zhou, G., Chen, S., \& Chen, Z. (2020). Back to the Spring of Wuhan: Facts and Hope of COVID-19 Outbreak. Frontiers of Medicine, 14(2), 113-116. https://doi.org/10.1007/s11684-020-0758-9

Zimoski, M.F., E. Muraki, R.J. Mislevy, \& R.D. Bock. (2003). BILOG MG. Chicago: University of Chicago.

Van der Linden, Wim J.; Barrett, Michelle D. (2016): Linking item response model parameters PL (Parameter Logistic) 